\title{
Study on variable condition model for steam turbine based on internal and external characteristics
}

\author{
Gang Liu ${ }^{*}$, Guang $\mathrm{Yu}^{2}$, and Qingyuan Xue ${ }^{1}$ \\ ${ }^{1}$ Da tang Northeast Electric Power Test Institute Co., Ltd., Changchun 130102, China \\ ${ }^{2}$ Aviation University of Air Force, Changchun 130021, China
}

\begin{abstract}
It is not easy to carry out the detailed variable condition calculation of steam turbine in engineering application. In this paper, a variable condition calculation model based on the internal and external characteristics of steam turbine is proposed, and a variable condition calculation model of constant power and constant flow is established. The model is applied to calculate $75 \%$ THA, 50\% THA, typical industrial and heating extraction conditions of a subcritical $330 \mathrm{MW}$ unit. The error is small compared with the design value, and the calculation accuracy meets the requirements. The results show that the model has high accuracy and can meet the requirements of engineering application.
\end{abstract}

\section{Introduction}

In recent years, the increase in power generation capacity of new energy sources has led to an increase in the time for coal-fired power plants to participate in deep peak shaving. The utilization hours of coal-fired power plants are decreasing year by year. In terms of operation evaluation, the importance of steam turbines variable-condition calculations has become increasingly prominent.

Existing steam turbine variable-condition calculation methods mainly include speed triangle method, semi-empirical curve method, detailed thermal calculation method, etc. In addition, the design data can also be used to simplify the calculation of the steam turbine flow and regenerative system to complete the parameter calculation. It is also possible to construct a variable condition calculation model according to the factory design parameters. Taking into account that the above methods are more practical, but not refined modeling, some scholars have proposed a high-precision calculation method for detailed variable operating conditions of steam turbines. This method combines the structural size data of the steam turbine and its ancillary equipment to establish a model analysis. Although the modeling is refined, it is also too cumbersome to practically apply in the general engineering field.

In response to above problems, this paper not only proposes a variable-condition calculation method based on the internal and external characteristics of the steam turbine units, but establishes a variable-condition calculation model. This method analyzes the

\footnotetext{
*Corresponding author: liugang19821029@163.com
} 
internal and external characteristics of the steam turbine on the basis of the Fryger formula, Bowman formula and stage characteristics analysis, which aims to avoid excessive simplification of the calculation model. This model is applied to a subcritical $330 \mathrm{MW}$ unit.The reliability of this method is verified by comparing the calculated values of each parameter under typical operating conditions with the design values.

\section{Variable-condition calculation model of steam turbine}

The characteristics of a steam turbine can be divided into external characteristics and internal characteristics. The external characteristics refer to the flow characteristics, and the internal characteristics mainly refer to the efficiency characteristics.

\subsection{External characteristic calculation model}

Existing literature often uses the Flugle formula to calculate the steam pressure at the extraction ports of the intermediate stages (groups) under variable operating conditions, This article also refers to this method to calculate the steam pressure at each extraction port and each cylinder inlet under variable conditions.

$$
\frac{G_{1}}{G}=\sqrt{\frac{p_{01}^{2}-p_{21}^{2}}{p_{0}^{2}-p_{2}^{2}}} \sqrt{\frac{T_{0}}{T_{01}}}
$$

In the formula: $\mathrm{p}_{0}$ indicates the pressure at the inlet of the steam turbine stage (group), $\mathrm{p}_{2}$ indicates the pressure at the outlet of the steam turbine stage (group), $\mathrm{T}_{0}$ Represents the absolute temperature of thermodynamics at the entrance of the stage(group), The subscript "1" means that the steam turbine has changed operating conditions, and the subscript without "1" means that the steam turbine has not changed operating conditions. In this paper, VWO operating conditions are selected as the benchmark operating conditions before variable operating conditions.

\subsection{Internal characteristic calculation model}

In the calculation of variable working conditions, according to the working characteristics of steam in different stage groups, Stage groups can be divided into three types: regulating stage, intermediate stage group and final stage group.

\subsubsection{Internal characteristic model of regulation stage}

There are currently three main methods for calculating the efficiency of the regulation stage under variable conditions: 1) Based on the structure data, carry out detailed variable condition calculation; 2) Characteristic curve method; 3) Semi-empirical formula. In this paper, the characteristic curve method is used to calculate the efficiency of the regulation stage.

\subsubsection{Internal characteristic model of intermediate pressure stage}

The intermediate pressure stage is located between the regulation stage and the final stage of the steam turbine, according to the relevant literature, if the temperature changes before each stage are not taken into account in the calculation of variable conditions, the internal efficiency of the stage is basically unchanged. At present, there are three main models for calculating the efficiency of the intermediate pressure stage: the former Soviet Union model, 
the Romanian model, and the American model. The following are respectively represented by formulas (2) (4):

$$
\begin{gathered}
\frac{\eta_{u_{\text {off }- \text { design }}}}{\eta_{u_{\text {design }, \text { optimal }}}}=2.10 \bar{x}_{\phi}-1.19 \bar{x}_{\phi}^{2}+0.09 \bar{x}_{\phi}^{3} \\
\frac{\eta_{u_{\text {off }- \text { design }}}}{\eta_{u_{\text {design optimal }}}}=\bar{x}_{\phi} \cdot\left(2-\bar{x}_{\phi}\right) \\
\frac{\eta_{u_{\text {off }- \text { design }}}}{\eta_{u_{\text {design,optimal }}}}=2 \cdot \frac{a}{\bar{x}_{\phi}} \cdot\left[\left(a-\frac{a}{\bar{x}_{\phi}}\right)+\sqrt{\left(a-\frac{a}{\bar{x}_{\phi}}\right)^{2}+1-a^{2}}\right]
\end{gathered}
$$

In the formula: $\mathrm{a}=0.7071, \bar{x}_{\phi}=\frac{\left(u / c_{a}\right)_{o f f-\operatorname{design}}}{\left(u / c_{a}\right)_{\text {design }}}$, Due to the peripheral speed of the stage before and after the variable working condition is unchanged, $\bar{x}_{\phi}$ is related to the ideal specific enthalpy drop of the stage This paper compares these three models and finds that the former Soviet Union model has the best agreement with the experimental data (see Figure 1). Therefore, the former Soviet Union model is used to calculate the efficiency of the intermediate pressure stage.

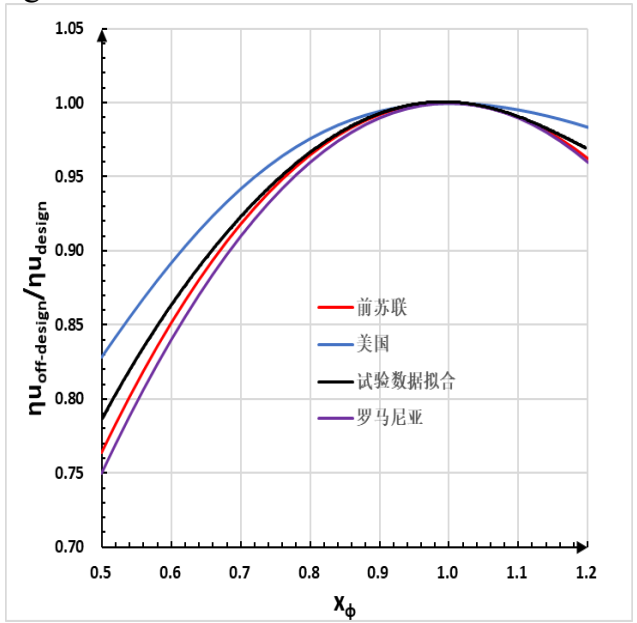

Fig. 1. Intermediate pressure stage efficiency model.

\subsubsection{Internal characteristic model of final stage}

The final stage of a large steam turbine is generally in the wet steam area, which makes it difficult to accurately determine the efficiency characteristics of the final stage under offcondition conditions. In engineering applications, it can still be considered that the influence of humidity on stage efficiency is linear, and the simplified Bowman formula is used to express it as:

$$
\eta_{u}^{\text {wet }}=\eta_{u}^{s . h} \cdot\left(1-a \cdot y_{m}\right)
$$


In the formula, $y_{m}=\left(y_{0}+y_{2}\right) / 2$ is average humidity of stage or stage group, a is the Bowman coefficient.

\section{Model accuracy verification}

This paper takes a subcritical 330MW, one-time reheat, three-cylinder and two-exhaust, single-shaft, extraction condensing steam turbine as a research object. The unit is equipped with a total of 7 stages of extraction steam, which respectively supply steam to 2 high pressure heaters, 1 deaerator and 4 low pressure heaters. The high pressure heater drains to the deaerator step by step. The low-pressure heater drains to the condenser step by step.

The characteristic curves of the steam turbine regulation stage $\mu-\varepsilon, \Omega \mathrm{m}-\varepsilon$, and $\eta \mathrm{u}-\mathrm{xa}$ are calculated as follows:

In order to verify the calculation accuracy of the regulation stage model, the regulation stage pressure and temperature under THA working condition, 75\% THA working condition and 50\% THA working condition are calculated using the above regulation stage characteristic curve. The calculation result and the design value are compared, see table 1.

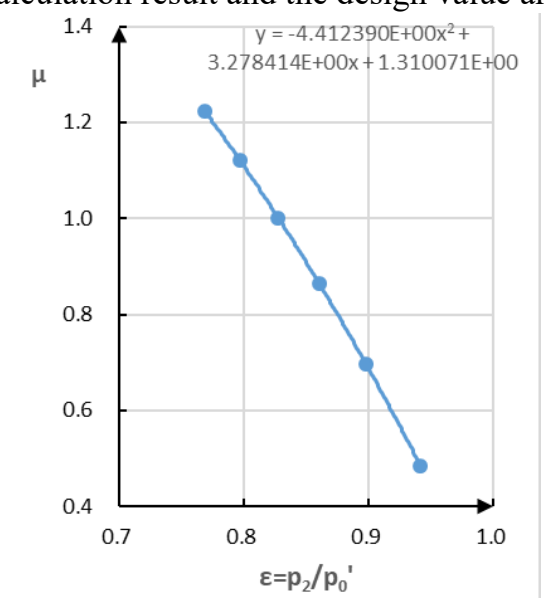

Fig. 2. $\mu-\varepsilon$ curve of steam turbine regulating stage.

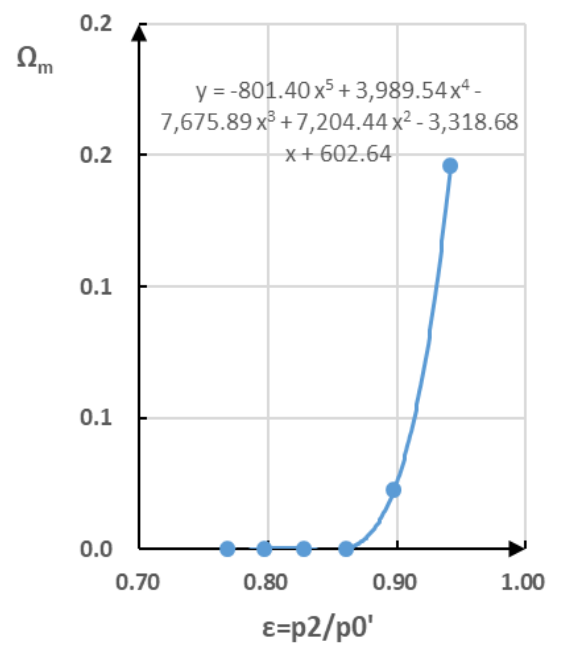

Fig. 3. $\Omega_{\mathrm{m}}-\varepsilon$ curve of steam turbine regulating stage. 


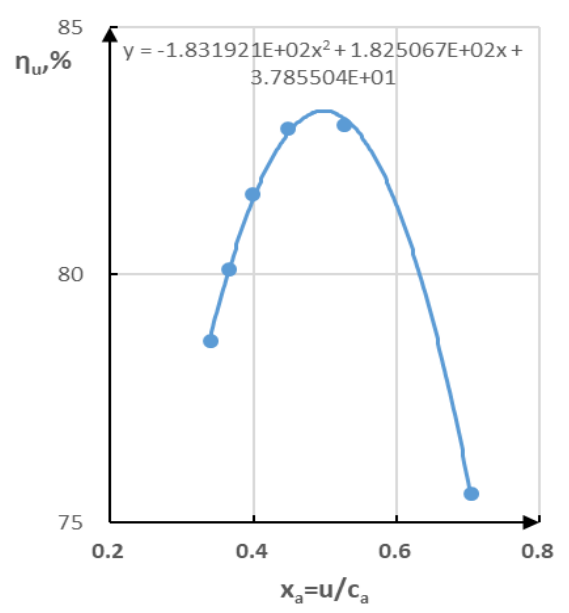

Fig. 4. $\eta_{u}-x a$ curve of steam turbine regulating stage.

Table 1. Comparison table of calculation results and design values of the regulation stage model.

\begin{tabular}{|c|l|c|c|c|c|}
\hline Condition & \multicolumn{1}{|c|}{ Parameter } & Units & $\begin{array}{c}\text { Design } \\
\text { value }\end{array}$ & $\begin{array}{c}\text { Calculation } \\
\text { result }\end{array}$ & $\begin{array}{c}\text { Error } \\
\text { value(\%) }\end{array}$ \\
\hline \multirow{2}{*}{ THA } & Regulation stage pressure & $\mathrm{MPa}$ & 13.546 & 13.490 & 0.41 \\
\cline { 2 - 6 } & $\begin{array}{l}\text { Regulation stage } \\
\text { temperature }\end{array}$ & ${ }^{\circ} \mathrm{C}$ & 502.41 & 503.59 & 0.23 \\
\hline \multirow{2}{*}{$75 \%$ THA } & Regulation stage pressure & $\mathrm{MPa}$ & 9.740 & 9.582 & 1.62 \\
\cline { 2 - 6 } & $\begin{array}{l}\text { Regulation stage } \\
\text { temperature }\end{array}$ & ${ }^{\circ} \mathrm{C}$ & 466.10 & 470.33 & 0.91 \\
\hline \multirow{2}{*}{$50 \%$ THA } & Regulation stage pressure & $\mathrm{MPa}$ & 6.560 & 6.343 & 3.31 \\
\cline { 2 - 6 } & $\begin{array}{l}\text { Regulation stage } \\
\text { temperatures }\end{array}$ & ${ }^{\circ} \mathrm{C}$ & 447.90 & 443.20 & 1.05 \\
\hline
\end{tabular}

It can be seen from Table 1 that the parameters calculated by the model have little deviation compared with the design values, which shows that the model has high accuracy. The calculation results of various working conditions can meet the requirements of engineering applications.

In order to further verify the reliability of the model, this section uses the VWO operating condition data as a benchmark, combined with the constant flow model to analyze the typical operating conditions of the subcritical 330MW unit. The comparison between the calculated results and the design values under typical working conditions such as 75\% THA, 50\% THA, and rated heating extraction is obtained, as shown in Table 2.

It can be seen from Table 2: The deviation between the calculated values of the parameters and the design values under the three operating conditions is relatively small. The maximum deviation between the calculated generator power and the design value does not exceed $0.35 \%$; the maximum deviation between the heat rate and the design value does not exceed $0.60 \%$. Therefore, this model can be used to calculate and predict the thermal performance parameters of the unit under variable operating conditions.

Table 2. Comparison of calculation results and design values under variable conditions.

\begin{tabular}{|c|c|c|c|c|c|c|c|c|}
\hline Operating condition & \multicolumn{2}{|r|}{ 75\% ТНА } & \multicolumn{3}{|c|}{$50 \%$ THA } & \multicolumn{3}{|c|}{$\begin{array}{l}\text { Industrial extraction steam } 125 \mathrm{t} / \mathrm{h} \text {, } \\
\text { heating extraction steam } 400 \mathrm{t} / \mathrm{h} \text {, } \\
\text { minimum power condition }\end{array}$} \\
\hline Paremeters & $\begin{array}{c}\text { Design } \\
\text { value }\end{array}$ & \begin{tabular}{|c|c|}
$\begin{array}{c}\text { Calculation } \\
\text { value }\end{array}$ & $\begin{array}{c}\text { Rate of } \\
\text { deviation }\end{array}$
\end{tabular} & $\begin{array}{c}\text { Design } \\
\text { value }\end{array}$ & $\begin{array}{c}\text { Calculation } \\
\text { value }\end{array}$ & $\begin{array}{c}\text { Rate of } \\
\text { deviation }\end{array}$ & $\begin{array}{l}\text { Design } \\
\text { value }\end{array}$ & $\begin{array}{c}\text { Calculation } \\
\text { value }\end{array}$ & $\begin{array}{c}\text { Rate of } \\
\text { deviation }\end{array}$ \\
\hline
\end{tabular}




\begin{tabular}{|c|c|c|c|c|c|c|c|c|c|}
\hline $\begin{array}{c}\text { Generator power } \\
\text { /MW }\end{array}$ & 247.692 & 248.567 & 0.35 & 165.205 & 164.788 & 0.25 & 219.553 & 220.219 & 0.30 \\
\hline $\begin{array}{c}\text { Heat } \\
\text { rate } /(\mathrm{kJ} /(\mathrm{kW} \cdot \mathrm{h}))\end{array}$ & 7974.60 & 7983.37 & 0.11 & 8341.14 & 8383.51 & 0.51 & 5754.90 & 5720.73 & 0.59 \\
\hline $\begin{array}{c}\text { Main steam pressure } \\
/ \mathrm{MPa}\end{array}$ & 17.750 & 17.750 & 0.00 & 17.750 & 17.750 & 0.00 & 17.750 & 17.750 & 0.00 \\
\hline $\begin{array}{c}\text { Main steam } \\
\text { temperature } /{ }^{\circ} \mathrm{C}\end{array}$ & 540.00 & 540.00 & 0.00 & 540.00 & 540.00 & 0.00 & 540.00 & 540.00 & 0.00 \\
\hline $\begin{array}{c}\text { Ragulation stage } \\
\text { pressure/MPa }\end{array}$ & 9.740 & 9.582 & 1.62 & 6.560 & 6.343 & 3.31 & 12.973 & 12.808 & 1.27 \\
\hline $\begin{array}{l}\text { Ragulation stage } \\
\text { temperature } /{ }^{\circ} \mathrm{C}\end{array}$ & 466.10 & 470.33 & 0.91 & 447.90 & 443.20 & 1.05 & 498.35 & 497.56 & 0.16 \\
\hline $\begin{array}{l}\text { High pressure } \\
\text { cylinder exhaust } \\
\text { pressure } / \mathrm{MPa}\end{array}$ & 3.114 & 3.092 & 0.71 & 2.061 & 2.027 & 1.65 & 3.663 & 3.535 & 3.49 \\
\hline $\begin{array}{l}\text { High pressure } \\
\text { cylinder exhaust } \\
\text { temperature } /{ }^{\circ} \mathrm{C}\end{array}$ & 309.30 & 303.77 & 1.79 & 294.68 & 291.82 & 0.97 & 319.35 & 315.50 & 1.21 \\
\hline $\begin{array}{l}\text { Reheat steam } \\
\text { pressure/MPa }\end{array}$ & 2.802 & 2.783 & 0.68 & 1.855 & 1.824 & 1.67 & 3.297 & 3.181 & 3.52 \\
\hline $\begin{array}{c}\text { Reheat steam } \\
\text { temperature } /{ }^{\circ} \mathrm{C}\end{array}$ & 540.00 & 540.00 & 0.00 & 540.00 & 540.00 & 0.00 & 540.00 & 540.00 & 0.00 \\
\hline $\begin{array}{c}\text { Second stage } \\
\text { extraction steam } \\
\text { pressure } / \mathrm{MPa}\end{array}$ & 1.535 & 1.526 & 0.59 & 1.032 & 1.010 & 2.13 & 1.759 & 1.721 & 2.16 \\
\hline $\begin{array}{c}\text { Second stage } \\
\text { extraction steam } \\
\text { temperature } /{ }^{\circ} \mathrm{C}\end{array}$ & 450.75 & 450.89 & 0.03 & 453.77 & 452.96 & 0.18 & 459.57 & 448.75 & 2.35 \\
\hline $\begin{array}{c}\text { Three-stage } \\
\text { extraction steam } \\
\text { pressure } / \mathrm{MPa}\end{array}$ & 0.724 & 0.721 & 0.41 & 0.510 & 0.504 & 1.18 & 0.819 & 0.804 & 1.83 \\
\hline $\begin{array}{c}\text { Three-stage } \\
\text { extraction steam } \\
\text { temperature } /{ }^{\circ} \mathrm{C}\end{array}$ & 345.80 & 346.11 & 0.09 & 354.80 & 355.26 & 0.13 & 352.35 & 342.51 & 2.79 \\
\hline $\begin{array}{c}\text { Four-stage } \\
\text { extraction steam } \\
\text { pressure } / \mathrm{MPa}\end{array}$ & 0.3514 & 0.3496 & 0.51 & 0.2486 & 0.2454 & 1.29 & 0.3900 & 0.3900 & 0.00 \\
\hline $\begin{array}{c}\text { Four-stage } \\
\text { extraction steam } \\
\text { temperature } /{ }^{\circ} \mathrm{C}\end{array}$ & 255.92 & 256.19 & 0.11 & 264.50 & 264.88 & 0.14 & 259.64 & 253.15 & 2.50 \\
\hline \begin{tabular}{|l|} 
Five-stage extraction \\
steam pressure /MPa
\end{tabular} & 0.0968 & 0.0961 & 0.72 & 0.0686 & 0.0677 & 1.31 & 0.0321 & 0.0325 & 1.25 \\
\hline $\begin{array}{c}\text { Five-stage extraction } \\
\text { steam temperature } \\
/{ }^{\circ} \mathrm{C}\end{array}$ & 132.29 & 132.46 & 0.13 & 139.04 & 139.70 & 0.47 & 133.52 & 127.16 & 4.76 \\
\hline $\begin{array}{c}\text { Six-stage extraction } \\
\text { steam pressure } / \mathrm{MPa}\end{array}$ & 0.0487 & 0.0493 & 1.23 & 0.0344 & 0.0350 & 1.74 & 0.0160 & 0.0162 & 1.25 \\
\hline $\begin{array}{c}\text { Six-stage extraction } \\
\text { steam temperature } \\
/{ }^{\circ} \mathrm{C}\end{array}$ & 80.71 & 80.99 & 0.35 & 80.38 & 83.71 & 4.14 & 74.84 & 74.34 & 0.67 \\
\hline $\begin{array}{c}\text { Seven-stage } \\
\text { extraction steam } \\
\text { pressure } / \mathrm{MPa}\end{array}$ & 0.0176 & 0.0181 & 2.84 & 0.0126 & 0.0134 & 6.35 & 0.0065 & 0.0068 & 4.62 \\
\hline $\begin{array}{c}\text { Seven-stage } \\
\text { extraction steam } \\
\text { temperature } /{ }^{\circ} \mathrm{C}\end{array}$ & 57.41 & 57.94 & 0.92 & 50.43 & 51.69 & 2.50 & 37.55 & 38.49 & 2.50 \\
\hline $\begin{array}{l}\text { Exaust Steam } \\
\text { pressure } / \mathrm{kPa}\end{array}$ & 0.0049 & 0.0049 & 0.00 & 0.0049 & 0.0049 & 0.00 & 0.0049 & 0.0049 & 0.00 \\
\hline
\end{tabular}




\section{Conclusion}

This paper proposes a steam turbine variable-condition calculation model based on internal and external characteristics, which is used to predict the thermal performance parameters of the unit. After comparing with the design parameters, it shows that its calculation accuracy fully meets the needs of engineering applications. The main contents are summarized as follows:

1) This paper proposes a variable-condition calculation method based on the internal and external characteristics of the unit, and establishes a constant-power and constant-flow variable-condition calculation model.

2) The regulation stage parameters of the steam turbine calculated by the characteristic curve have high accuracy, which fully meets the requirements of engineering applications.

3) This paper takes a subcritical $330 \mathrm{MW}$ unit as an example, and uses a constant flow model to calculate various parameter values under typical operating conditions such as THA, $75 \%, 50 \%$ THA, industrial and heating extraction. The maximum deviation between the calculated value of generator power and the design value does not exceed $0.35 \%$; the maximum deviation between the calculated value of heat rate and the design value does not exceed $0.60 \%$.

4) This model has certain reference significance for the same type of heating units. In the case of frequent changes in working conditions, it can improve the operating efficiency and operating economy of the unit.

\section{References}

1. B Wang, Y Z Zhao. Quantitative analysis of energy consumption for cylinder efficiency of a Shanghai electric - siemens ultra-supercritical $660 \mathrm{MW}$ steam turbine unit[J]. IOP Conference Series: Earth and Environmental Science,2018,188(1).

2. Shihe Chen, Hailin Fang, Yaqing Zhu, Yanfen Liao, Kai Su, Xiaowei Peng, Xiaoqian Ma. Energy-loss Analysis of Thermal Power Unit Based on Multifactor Disturbance Theory[J]. Energy Procedia,2017,105.

3. De Liang Zeng, Shu Wen Diao, Yong Hu, Shan Gao, Qing Li. Influence of Condensed Water Temperature on Thermal Efficiency of Coal-Fired Power Plant and Energy Strategy[J]. Advanced Materials Research,2014,3249.

4. Shan Tu, Qi Zhou, Jian Liu Jian, Cong Qiang Ding, Shu Ming Wu. Application Study on Low Vacuum Circulating Water Heat Supply of a 50 MW Turbine[J]. Advanced Materials Research,2014,3249.

5. Yu Zhu, Qian Jun Li, Li Kun Zheng, Yong Xin Feng. Research on the 330MW Double-Extraction Steam Turbine of Dynamic and Thermal Characteristics Analysis Model[J]. Applied Mechanics and Materials,2014,2900.

6. Sha Liu, Pei Hong Wang, Zhi Gang Su. The Exhaust Steam Enthalpy of Steam Turbine Cognitive Modeling Based on Simplify Evidential Regression Multi-Model[J]. Advanced Materials Research,2013,2116. 